\title{
The effectiveness of psychoeducational and McMaster approaches on increasing cohesion- flexibility of couples
}

\author{
Seyed Jamaleddin Nabavi ${ }^{1}$, Baqher Sanai Zaker ${ }^{2}$, Alireza kiyamanesh ${ }^{2,3}$ \\ ${ }^{1}$ PhD Candidate of counselling, Department of counselling, Faculty of humanities and social sciences, Science and \\ Research Branch, Islamic Azad University, Tehran, Iran \\ ${ }^{2}$ Professor, Department of Counseling, Faculty of Psychology and Education, Kharazmi University, Tehran, Iran \\ ${ }^{3}$ Professor, Science and Research Branch, Islamic Azad University, Tehran, Iran
}

\begin{abstract}
Background: The purpose of this study was to investigate the effect of psychoeducational (relationship enrichment) approach and McMaster theory on increasing cohesion-flexibility of couples.

Materials and methods: From among 60 volunteer couples, 24 were randomly selected and divided into two experimental groups of psychoeducational (8 males and 8 females) and McMaster (8 males and 8 females), and one control group ( 8 males and 8 females). Each of the experimental groups was separately trained in 10 sessions over a three-month period based on the psychoeducational (RE) and McMaster approaches. The participants in the three groups were evaluated by the marital cohesion -flexibility questionnaire in three stages of pre-test, post-test, and follow-up period. Chi-squared was used to analyze data.

Results: The results of the study indicated that the psychoeducational relationship enrichment model and the McMaster model didn't significantly increase cohesion - flexibility among couples ( $\mathrm{P}>0.05)$.

Conclusion: Cohesion and flexibility among spouses are seen in a linear continuum that shows the central points of healthy relationships. Cohesion shows the degree of dependence and independence between spouses and flexibility shows the ability of the marital system as an effective substitute for stress and changes. In this study, two psychoeducational and McMaster's approaches did not succeed to improve cohesion and flexibility between couples.
\end{abstract}

Keywords: Cohesion, Flexibility, Psychoeducational, McMaster.

Cited as: Nabavi SJ, Sanai Zaker B, Kiyamanesh AR.The effectiveness of psychoeducational and McMaster approaches on increasing cohesion- flexibility of couples. Medical Science Journal of Islamic Azad University, Tehran Medical Branch 2019; 29(1): 83-91.

Correspondence to: Bagher Sanai Zaker

Tel: +982188524040

E-mail: bsanai@yahoo.com

ORCID ID: 0000-0001-9387-5938

Received: 11 Mar 2018; Accepted: 29 May 2018 
مجله علوم بزشكى دانشگاه آزاد اسلامى

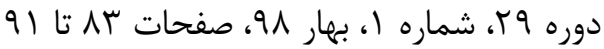

Original

Article

\title{
مقايسه اثر بخشى زوج درمانى به شيوه يربارسازى رابطه و رويكرد مك مستر در افزايش همبستگى -انعطاف يذيرى زوجها
}

\author{
سيد جمال الدين نبوى'، باقر ثنائى ذاكر '، عليرضا كيامنش ‘rrr
}

\author{
' ل دانشجوى دكتراى مشاوره، واحد علوم و تحقيقات، دانشعاه آزاد اسلامى، تهران، ايران

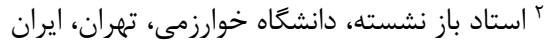

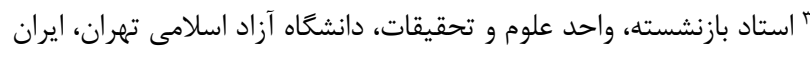

קكيده

سابقه و هدف: يثزوش حاضر به منظور بررسى تاثير رويكرد بربار سازى رابطه و رويكرد مكى مستر در بهبود همبستكى- انعطاف

$$
\text { بذيرى در بين همسران انجام شد. }
$$

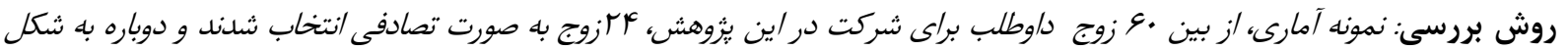

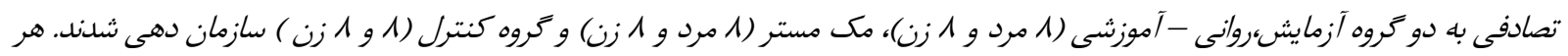

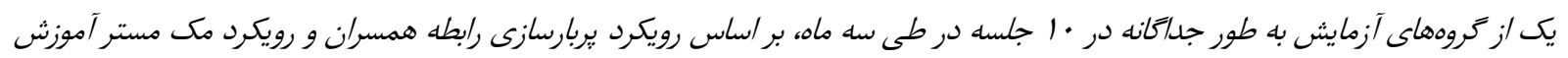

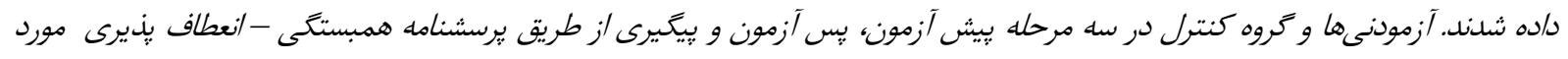

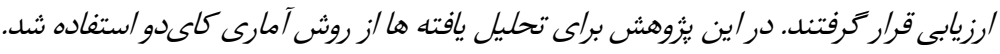

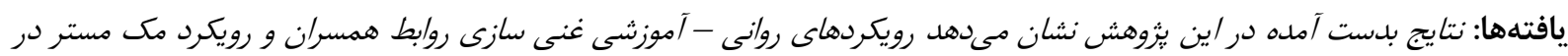

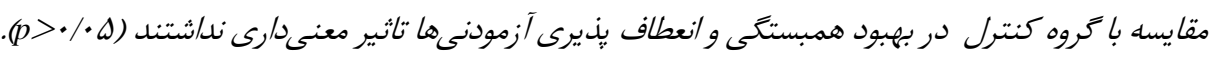

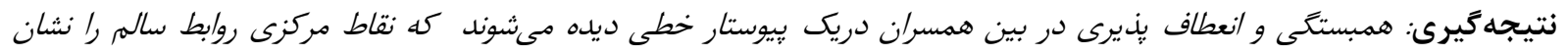

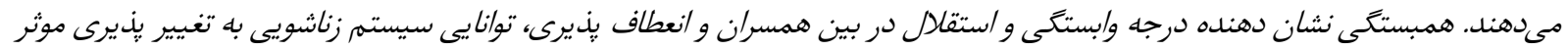

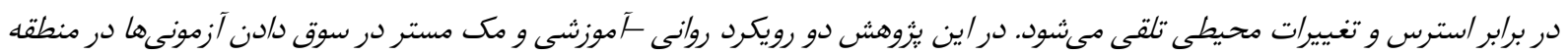

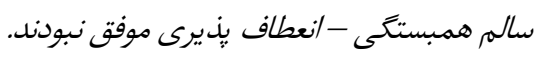
وازكان كليدى: همبستكى، انعطاف بِّيرى، بربارسازى رابطه، مكى مستر.

شهروندانى شاداب، سرزنده و مسؤل، وجود يك خانواده

مقدمه - مق

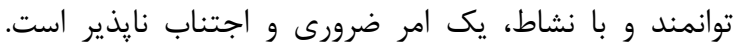
ستون اصلى و قلب يك خانواده، روابط زن و شوهر با يكديكر

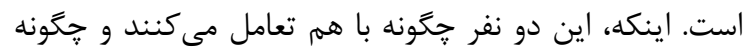

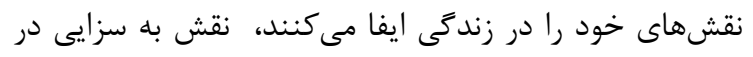

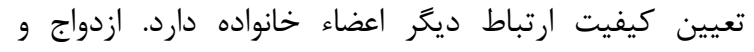

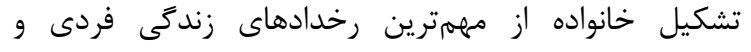

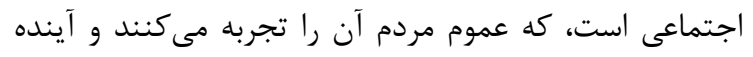
خانواده يكى از اصلىترين نهادهاى اجتماعى تاثيركذار بر

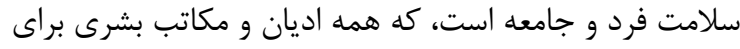

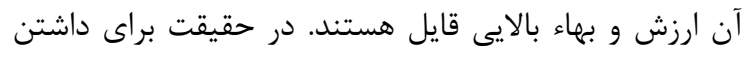

آدرس نويسنده مسئول: تهران، دانشكاه خوارزمى، دكتر باقر ثنايى ذاكر (email: bsanai@yahoo.com) ORCID ID: 0000-0001-9387-5938

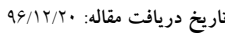
تاريخ يذيرش مقاله: 9V/T/N 
همان طور كه در شكل I ديده مىشود، دامنه يِيوستار

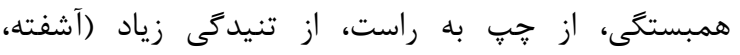
غيرتعاملى)، كه با الخوهاى تسليم- سلطه شناسايى مىشود، رَّل تا توانايى زياد در برقرارى مراودات موفق و تساوى طلبانه، نوسان دارد. محور عمودى، انعطاف يذيرى خانواده را به يه

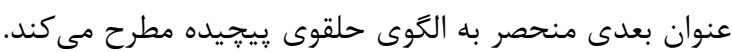
״يوستار اين محور، از خشك (يايين ترين نقطه) تا آشفته (بالاترين نقطه)، كشيده شده است. اين نمودار براى طبقه

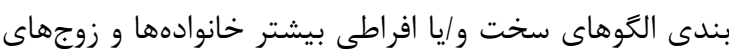
ناكارآمد و سبكهاى منعطف تر خانوادههاى كارآ، ترسيم شده است. بر اين اساس، خانوادههاى سالم سبك خانوادگى

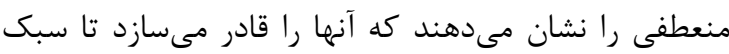
رفتارى رشدى، فردى و خانوادگى را در طول زمان تغيير

دهند.

دياگرام الكوى سنجش و ارزيابى ييجيده حلقوى خانواده و زوج در مجموع، همبستخى به معناى بودن با يكديگر، بدون سلب آرامش شخصى يا تخطى از اصول فردى بين اعضاى

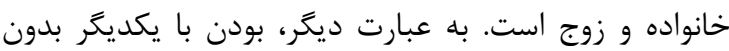
تجاوز به حريم شخصى و خصوصى همسر. اين ييوستار براساس يك منحنى تعريف شده است، جرا كه دو انتهاى اين ييوستار شكل ناكارآمدى به خود مى خيرند و ميانه آن نشان دهنده سلامت مراودات بين فردى است. هر جه همسران هران در شكل بودن با يكديكر، به حريم شخصى يكديگر احترام

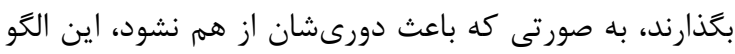
سالمتر است و بالعكس (ه). با توجه به اهميت موضوع همبستكى - انعطاف يذيرى دردوام و بقا و كيفيت روابط بين همسران، نظريههاى متعددى درمشاوره خانواده، به اين

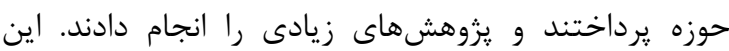
رويكردها سعى دارند تا با نظريه يردازى و مداخلات درمانى تره

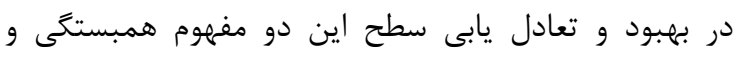

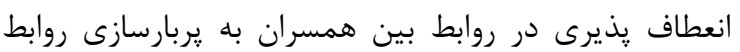

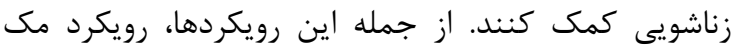
مستر و رويكرد روانى - آموزشى غنى سازى روابط بين

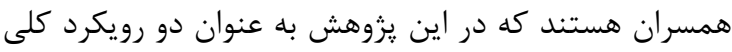
نتر و جزيى نخر براى آموزش زوج ها استفاده شده است.

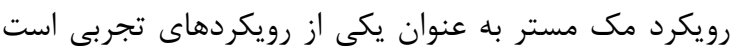

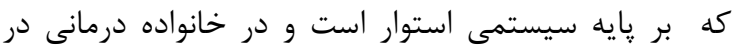
زمينه ارزيابى عملكرد خانواده و نقش آن درحل مشكلات و و بهبود كيفيت كاركرد خانواده موفق است. در اين الكو، ساختار، جگَّنگى سازماندهى و الخوهاى تبادلى خانواده مورد
آنها را تحت تاثير قرار مىدهد. عاملى كه باعث ادامه زندگى و يايدارى يك رابطه مىشود، علايق و ارزشهاى مشترك است.

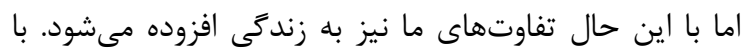
وجود تفاوتها، زوجها مىتوانند يكديگر را در عين حمايت، يربار و كامل سازند (1). اين نخستين نهاد طبيعى و اجتماعى، جونان ييكرهاى قدرتمند، عملكردهاى اجتماعى، فيزيكى و روانى اعضايش را تحت تاثير قرار مىدهد و مىتواند جهت

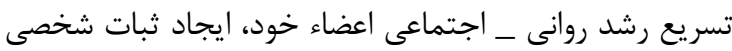

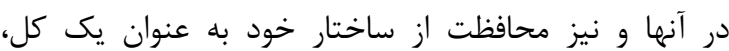

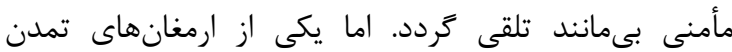

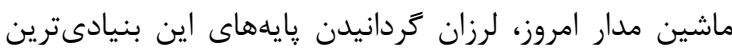

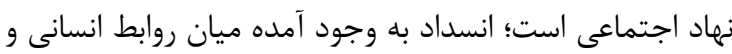
فروياشى جهل درصدى زيوندهاى زناشويى در دهلهاى كذشته گواهانى بر صحت اين ادعا است (r). امروزه جهت مقابله با مسايل ديريا و مختل كننده خانوادكى، كاني، راه حلها و دستورالعملهايى كارآمد در دست است و تعداد روز افزون كتب و يزوهش در اين زمينه گَواهى است بر صحت اين كفتار. اما با وجود اين همه قانون كارساز و علم، بسيارى از خانواده ها ييرامون اين قوانين، هم اكنون نزديك به نيمى از

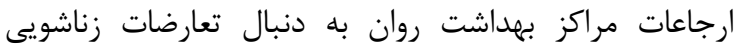

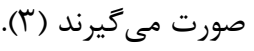
يكى از موضوعات اساسى و مهرم در روابط بين همسران، نسبت بين همبستخى و انعطاف يذيرى در اين رابطه است. يكى از نظريههاى مهمم در اين زمينه، الكوى سنجش خانواده و زوج

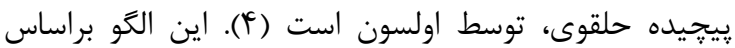
ملاكهاى اصلى همبستخى، انطباق يذيرى و ارتباط، خانواده و زوج مراجعه كننده را درجه بندى و دسته بندى ميى كند.

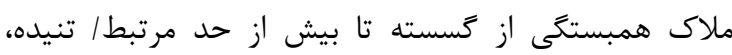
متغير است و ابعادى مانند يِيوند عاطفى، ارتباط خانوادگى،

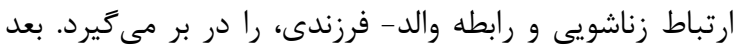

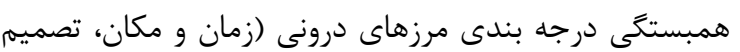

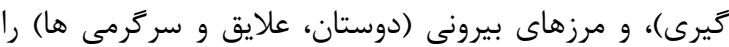
هم دربر مى گيرد.

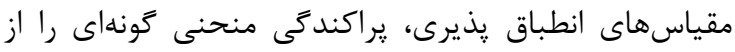
عدم انعطاف يذيرى (خشك) تا منعطف و بيش از حدى منعطف و آشفته، ارائه مى دهد و شامل خرده مقياس هاى زير است: رهبرى (از سلطه گرى تا رهبرى ضعيف)، نظم (از ديكتاتورى تا هرج و مرج)، مذاكره (از تحميل نظرات تان تصميمات تكانشى)، نقشها (از خشك تا متغير)، و قوانين (از نامنطف تا ساختار قانونى معين). 


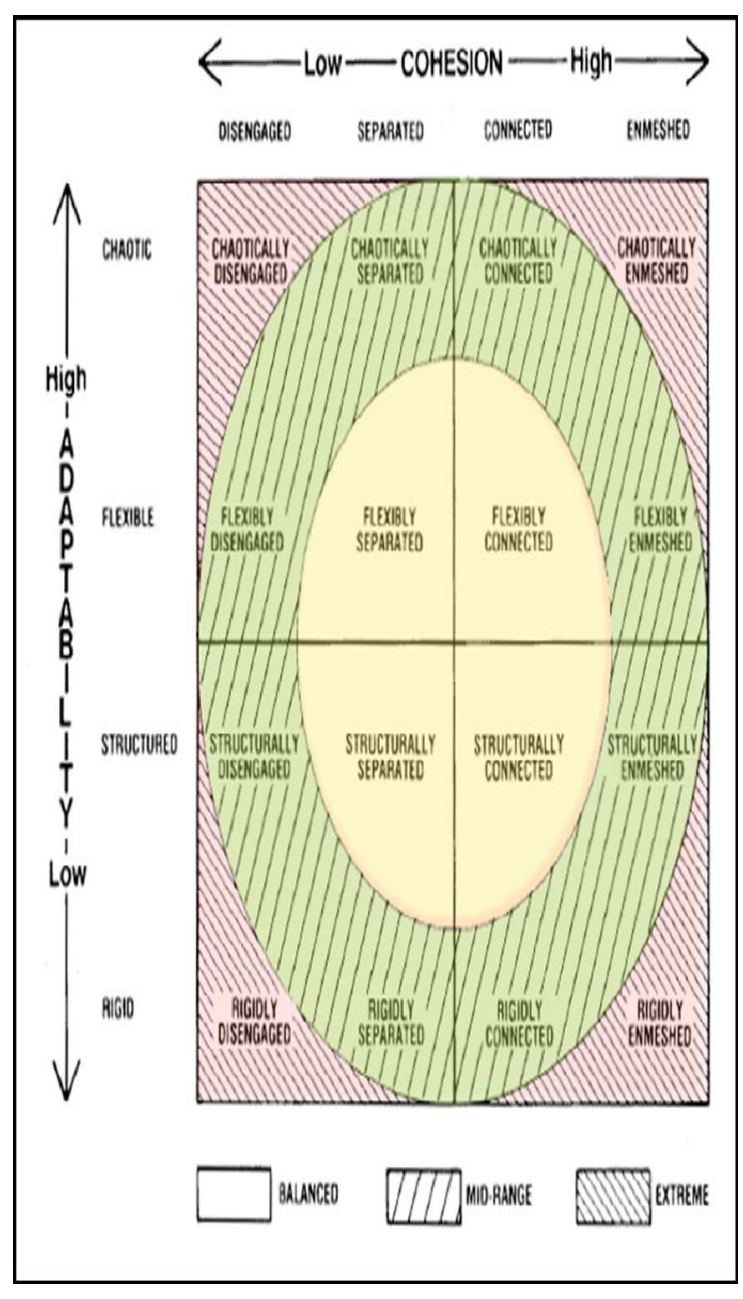

شكل ا. الكَى سنجش و ارزيابى پيجٍيده حلقوى خانواده و زوج

اين يزوهش در صدد است تا براساس ديدگاه مك مستر به

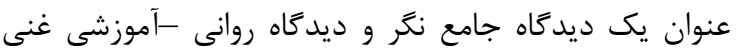
سازى رابطه بعنوان يك الكَى رابطه محور، به مولفه مهيهم دئه

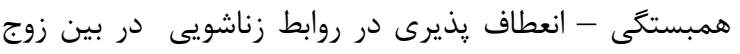

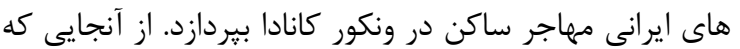
براساس مطالعات و مشاهدات انجام شده در بين زوجهاى

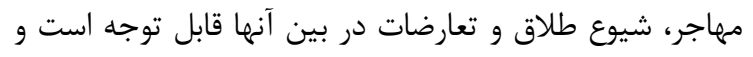

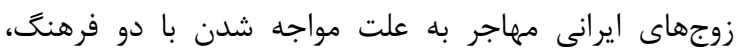
شرقى و غربى، در تعادل بخشى بين ميزان استقلال و و

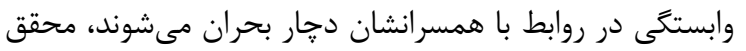

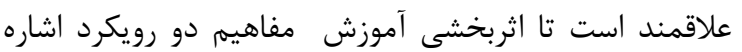

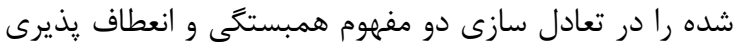
در روابط زناشويى را بررسى كند.
بررسى قرار مى گيرد. اصول بنيادين اين الكو عبارت است ازئ ارتباط بين بخشها و اجزاى خانواده با يكديكر، قابل درى نبودن يك جزء جداى از ساير اجزاى خانواده، نقش مهرهم ساختار و الكَوهاى تعاملى خانواده در تعيين و شكل دائ دهى آنى

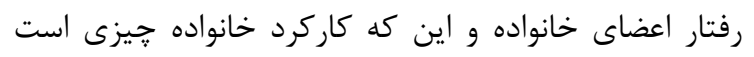

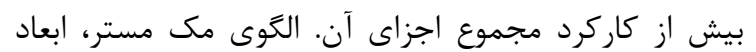

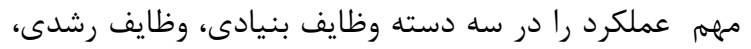

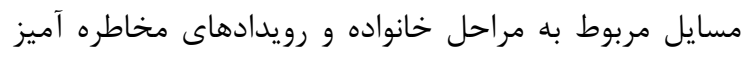

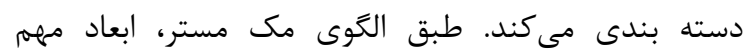

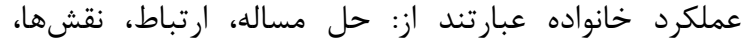

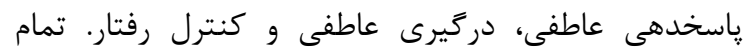

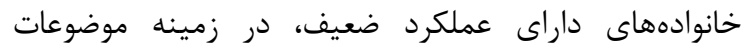

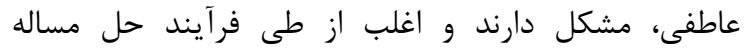

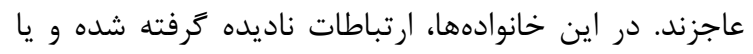

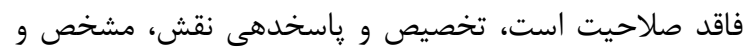
واضح نيست، گستره واكنشهاى هيجانى، محدود بودهن،

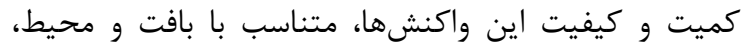

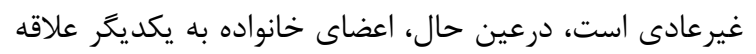

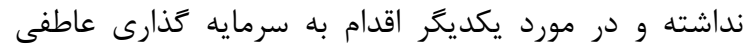

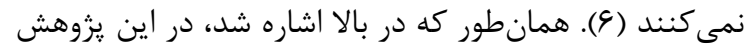

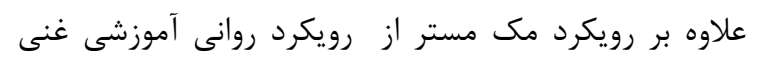

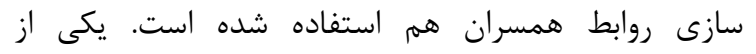
عمدهترين رويكردهاى مطرح در زمينه زوجى و زمان زناشويى،

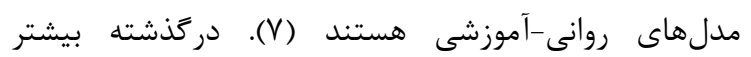

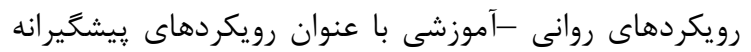
مطرح بودند. على رغم تفاوتهاى موجود بين بيشخيرى و

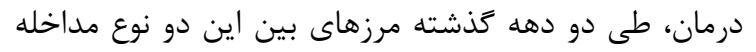

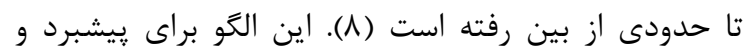

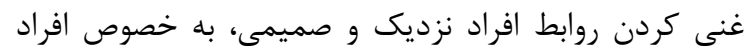

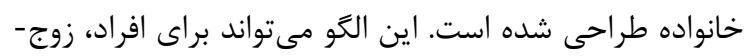

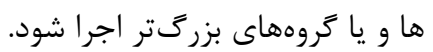
هدف اين الكَ، افزايش رضايت روانشناختى و عاطفى موجود إنى

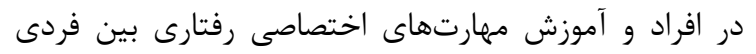

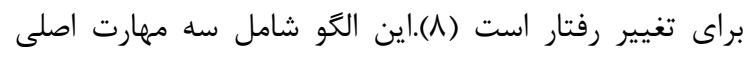
همدلى، ابراز فكر و احساس و بحث و كَفتكو است. در كنار

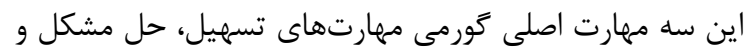

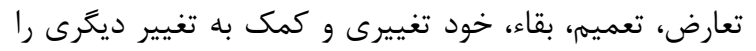

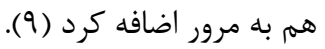




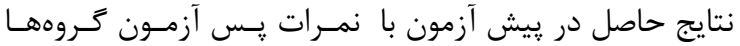

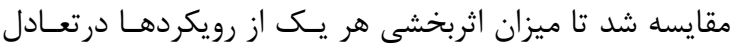

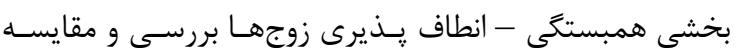
شود. در نهايت به منظور بررسى ماندكارى اثر متغير آزمايشى،

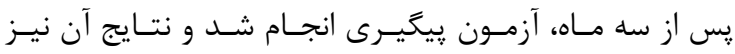

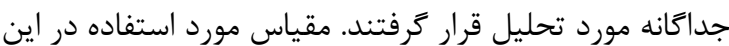
يروهش ارزيابى همبستكى و انعطاف پـذـيرى اسـت كـه ابتـدا،

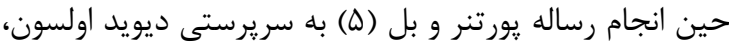

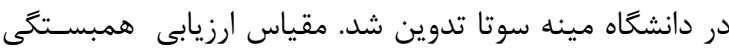

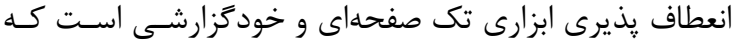

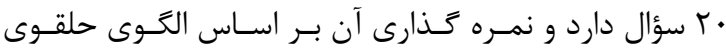

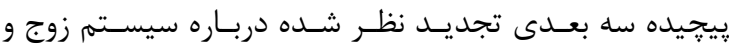

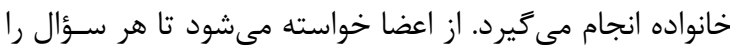

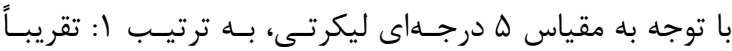

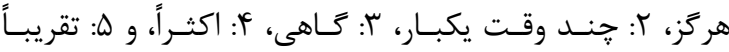

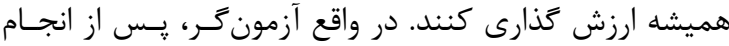

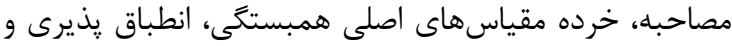

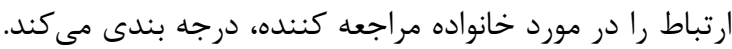

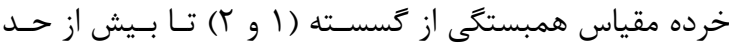

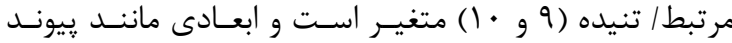

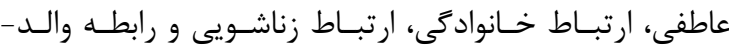

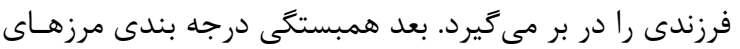

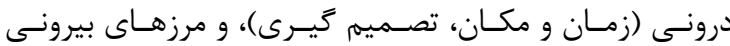

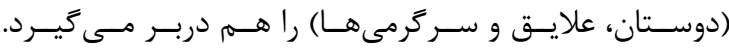

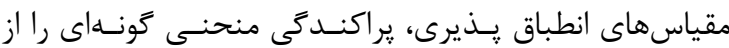

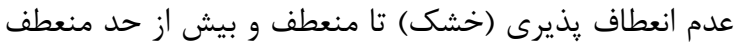

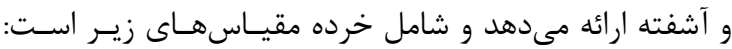
رهبرى (از سلطه گرى تا رهبرى ضعيف)، نظم (از ديكتـاتورى

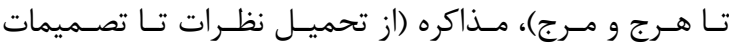

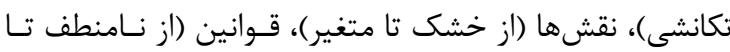

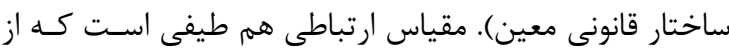

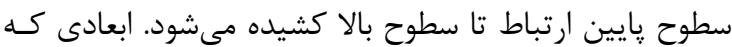

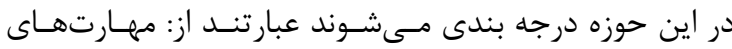

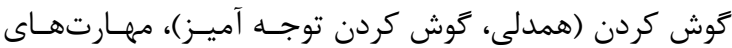

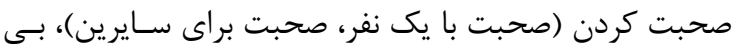
يرده گويى، وضوح ارتباطى، تداوم در ارتباط، احترام و بذيرش.

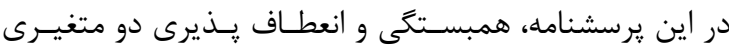

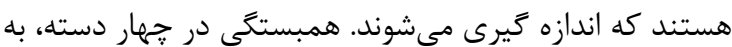

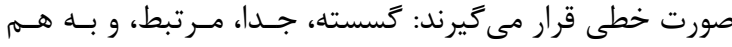
تنيده. انعطاف يذيرى هم به همين ترتيب به جهار كروه

\section{مواد و روشهها - ماد}

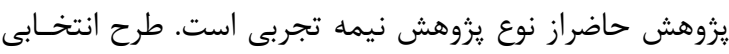

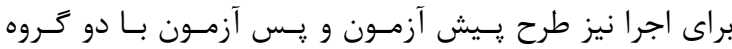

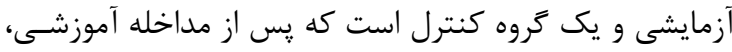
مورد مشاهده و اندازه كيرى قرار گرفتند.

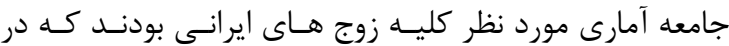
مدارس سطح شهر ونكوور كانادا فرزندانشان در حـال تحصـيل

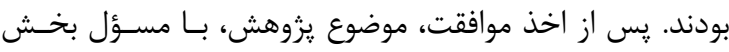

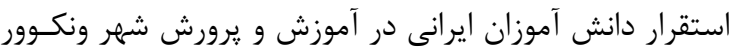

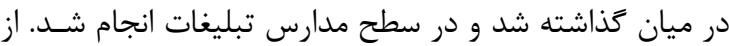

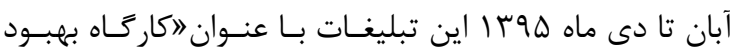

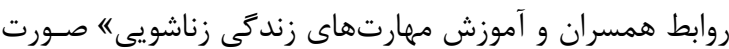

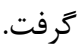

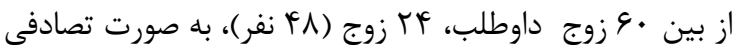

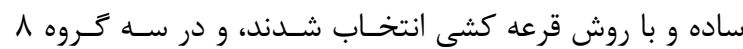
زوجى (عانفره، هر گروه شامل ^ زن و 1 مرد) قرار گرفتند.

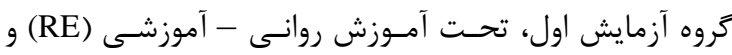

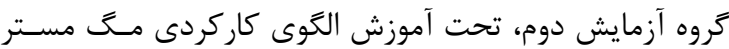

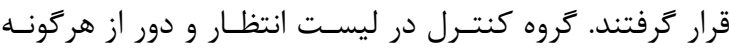
مداخله آموزشى بودند.

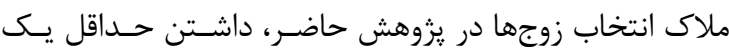
فرزند، تحصيلات دانشـاهي، داشـتن حـداقل ه سـال سـابقه ازدواج و بالاى س سال اقامت در كانادا بود.

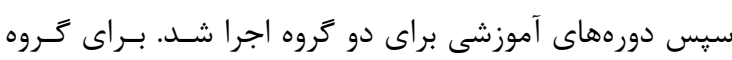

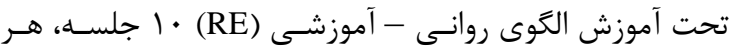

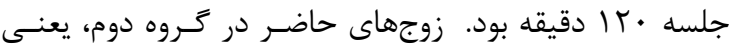

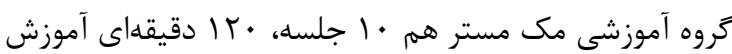
داده شدند. در هر هفته يك جلسه آموزشى براى هر كروه اجرا

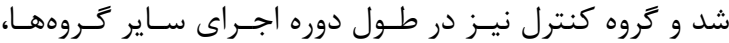

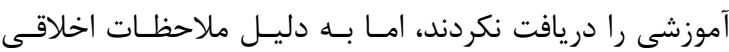

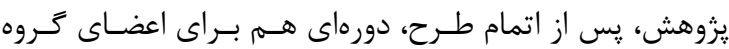

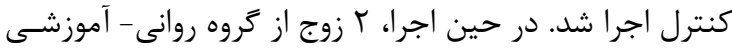

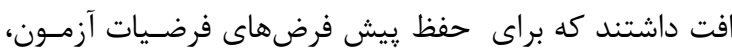
نتايج دو زوج، به صورت تصادفى از كروه مك مسـتر و دو زوج از گروه كنترل كنار كذاشته شدند. در نهايت از هر كروه

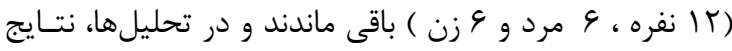

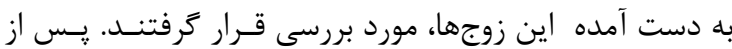
اتمام دورههاى آموزشى و در جلسه آخر هر كروه، يس آزمــون

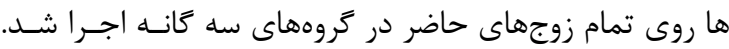




\begin{tabular}{|c|c|c|c|c|c|c|}
\hline كل & كنترل & پس آزمون & يِش آزمون & & & \\
\hline re & Ir & IT & IT & كنترل & مجموع & \\
\hline re & IT & IT & IT & روانى آموزشى & & \\
\hline re & IT & IT & ir & مك مستر & & \\
\hline 1. & $r$ & r & $r$ & كنترل & & \\
\hline$\Delta$ & 1 & . & r & روانى آموزشى & آشفته & \\
\hline r & 1 & 1 & r & مك مستر & & \\
\hline V & r & r & r & كنترل & منعطف & \\
\hline If & $\Delta$ & $\Delta$ & r & روانى آموزشى & & \\
\hline $1 \pi$ & r & $\Delta$ & r & مك مستر & & انعطاف يذيرى \\
\hline$\Delta$ & r & $r$ & 1 & كنترل & باساختار & \\
\hline 1 & f & i & r & روانى آموزشى & & \\
\hline ir & $\Delta$ & r & r & مك مستر & & \\
\hline ir & $r$ & $r$ & r & كنترل & سخت & \\
\hline 1 & f & i & $r$ & روانى آموزشى & & \\
\hline$\wedge$ & $r$ & r & $r$ & مك مستر & & \\
\hline re & Ir & IT & Ir & كنترل & مجموع & \\
\hline re & IT & IT & IT & روانى آموزشى & & \\
\hline re & IT & IT & IT & مك مستر & & \\
\hline 11 & $r$ & i & $r$ & كنترل & تنيده & \\
\hline r & r & f & $\Delta$ & روانى آموزشى & & \\
\hline$\wedge$ & $r$ & $r$ & r & مك مستر & & \\
\hline 4 & 1 & $r$ & $r$ & كنترل & مرتبط & \\
\hline 19 & $\Delta$ & 4 & $\Delta$ & روانى آموزشى & & تخكى \\
\hline ir & r & r & $\Delta$ & مك مستر & & \\
\hline V & r & r & r & كنترل & جدا & \\
\hline$\wedge$ & $r$ & $r$ & r & روانى آموزشى & & \\
\hline r & 1 & 1 & r & مك مستر & & \\
\hline ir & f & r & r & كنترل & كسسته & \\
\hline 4 & 1 & $r$ & r & روانى آموزشى & & \\
\hline$\wedge$ & r & r & r & مك مستر & & \\
\hline
\end{tabular}

مفاهيم همبستگى و انعطاف يذيرى در قالب يك ييوستار ديده مىشوند و دو انتهاى اين يیيوستار نشان دهنده روابط سـالم در

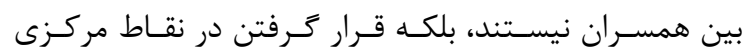

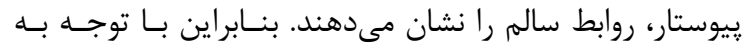

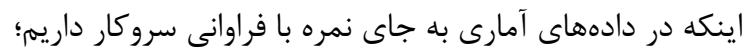

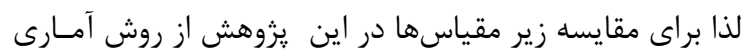
كاىدو براى تحليل استفاده شد.

بافتهها

دادهاى جدول ا فوق نشانكر ميزان فراوانى گروههاى روانى -

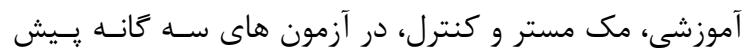

تقسيم مىشود: سخت، باسـاختار، منعطـف، و آشـفته. نمـرات

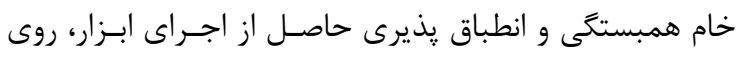

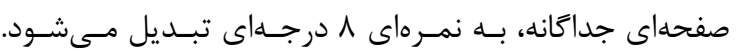
ميانگين نمرات دو مقياس محاسبه شده، تا با يكى از اين جهار

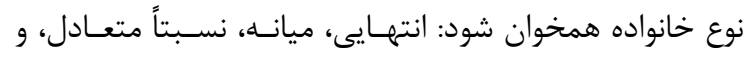

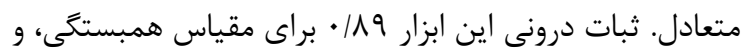

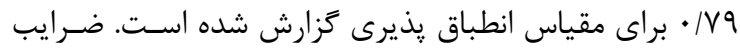

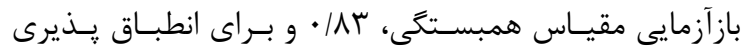

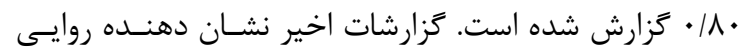
صورى و افتراقى قابل قبولى هستند (IV) (V). در يـرّوهش حاضـر

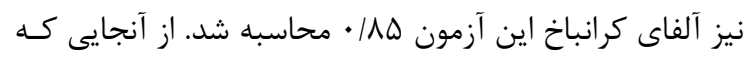


جدول ז. آزمون كاىدو براى مقايسه نسبت (فراوانى) در سطوح مختلف انعطاف يذيرى و گروههاى مختلف در يِيش آزمون

\begin{tabular}{|c|c|c|c|c|}
\hline سطح معنى دارى دقيق & سطح معنى دارى & درجه آزادى & مقدار آماره كاىدو & \\
\hline$\cdot / \Lambda V T$ & $\cdot|\wedge \Delta|$ & 4 & r/GYA & كاى \\
\hline 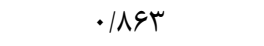 & ./Ard & 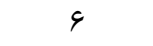 & r/VAN & نسبت درست نمايى \\
\hline$\cdot \mid \Lambda V T$ & & & r/AVq & آزمون دقيق فيشر \\
\hline
\end{tabular}

جدول ب. آزمون كاىدو براى مقايسه نسبت (فراوانى) در سطوح مختلف انعطاف يذيرى و گروههاى مختلف در يس آزمون

\begin{tabular}{|c|c|c|c|c|}
\hline سطح معنى دارى دقيق & سطح معنى دارى & درجه آزادى & مقدار آماره كاىدو & \\
\hline.$/ 4 \Delta q$ & ./FTF & 4 & $\Delta / ৭ ৭ \Delta$ & كاى \\
\hline.$/ 499$ & . TSG & 4 & G/Drr & نسبت درست نمايى \\
\hline .1099 & & & $\Delta / \backslash \Delta \varphi$ & آزمون دقيق فيشر \\
\hline
\end{tabular}

جدول f. آزمون كاىدو براى مقايسه نسبت (فراوانى) در سطوح مختلف انعطاف يذيرى و گروههاى مختلف در يِيخيرى

\begin{tabular}{|c|c|c|c|c|}
\hline سطح معنى دارى دقيق & سطح معنى دارى & درجه آزادى & مقدار آماره كاىدو & \\
\hline$\cdot / 9 \Delta \varphi$ & .1814 & 4 & F/^Ar & كاىدو \\
\hline$\cdot / V T \Lambda$ & - /gFF & 4 & f/rmq & نسبت درست نمايى \\
\hline$\cdot / V T \Delta$ & & & $F / I r v$ & آزمون دقيق فيشر \\
\hline
\end{tabular}

با توجه به مقدار آمار كاىدو 9 • 1/ با ب درجه آزادى و آزمون

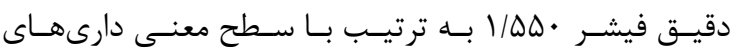

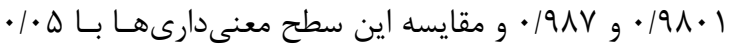

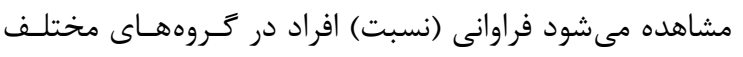

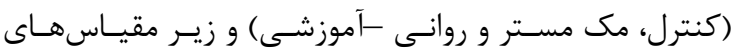

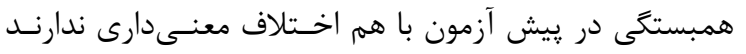

$$
\text { ( })(\mathrm{p}>\cdot|\cdot|)
$$

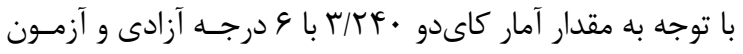

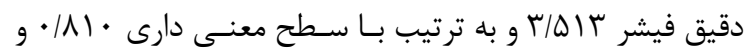

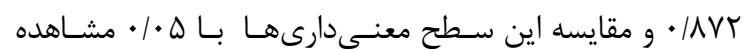

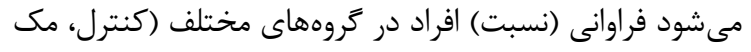

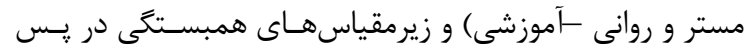

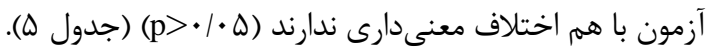

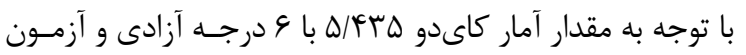

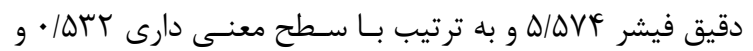

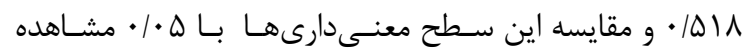

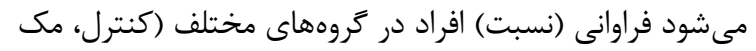

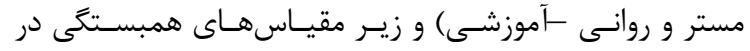
ييخيرى با هم اختلاف معنى دارى ندارند (ه • ••p) (جدول و ع).
آزمون، پِ آزمون و پِيكيرى، به تفكيك خـــده مقيـاس هـاى انعطاف يذيرى - همبستكى است.

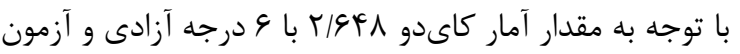

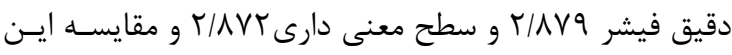
سطح معنى دارى با هـ • • مشاهده مى شــود فراوانسى (نسـبت)

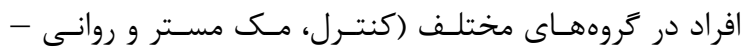

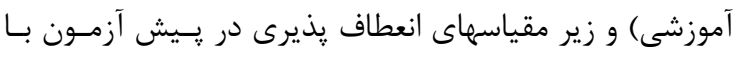

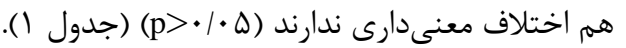

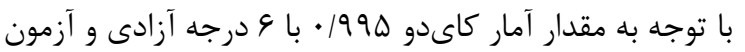

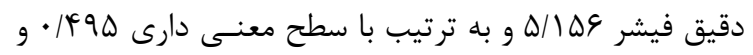

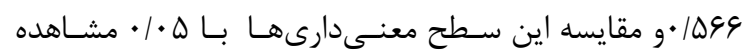

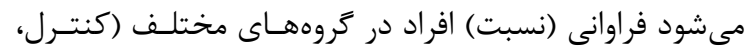

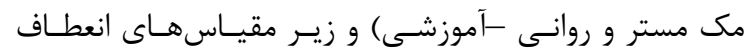

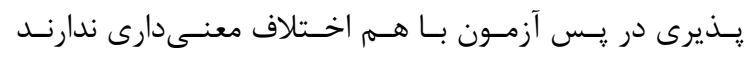
( $(\mathrm{p}>\cdot / \cdot \Delta)$

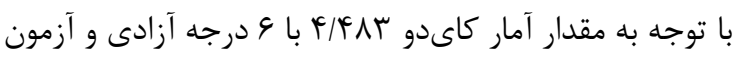

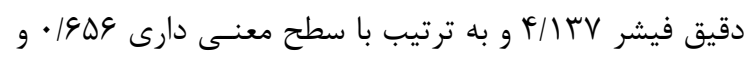

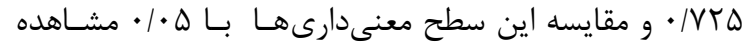

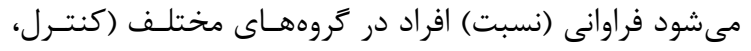

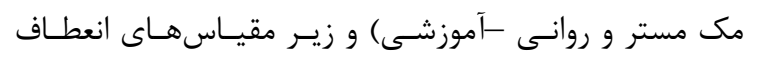

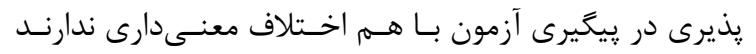

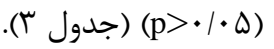


جدول ه. آزمون كاى دو براى مقايسه نسبت (فراوانى) در سطوح مختلف همبستخى و گروههاى مختلف در بيش آزمون

\begin{tabular}{|c|c|c|c|c|}
\hline سطح معنى دارى دقيق & سطح معنى دارى & درجه آزادى & مقدار آماره كاىدو & \\
\hline.$/ 91$. &.$/ 9 \vee 9$ & 4 & $15 \cdot 9$ & كاى \\
\hline$\cdot / 9 \wedge \vee$ &.$/ 9 \vee 4$ & 4 & 1/Tr & نسبت درست نمايى \\
\hline$\cdot / 9 \wedge \vee$ & & & $1 / \Delta \Delta$ & آزمون دقيق فيشر \\
\hline
\end{tabular}

جدول و. آزمون كاى دو براى مقايسه نسبت (فراوانى) در سطوح مختلف همبستگى و گروههاى مختلف در يس آزمون

\begin{tabular}{|c|c|c|c|c|}
\hline سطح معنى دارى دقيق & سطح معنى دارى & درجه آزادى & مقدار آماره كاىدو & \\
\hline$\cdot|\wedge|$ & $\cdot / V \vee \wedge$ & 4 & $r / T F$. & كاى \\
\hline ./V^s & ./VDr & 4 & $r / f r$. & نسبت درست نمايى \\
\hline . /VAr & & & r/DIr & آزمون دقيق فيشر \\
\hline
\end{tabular}

جدول V. آزمون كاى دو براى مقايسه نسبت (فراوانى) در سطوح مختلف همبستكى و گروههاى مختلف در ييخيرى

\begin{tabular}{|c|c|c|c|c|}
\hline سطح معنى دارى دقيق & سطح معنى دارى & درجه آزادى & مقدار آماره كاىدو & \\
\hline D & $\cdot / 4 \wedge 9$ & 4 & $\Delta / \mathscr{A r} \Delta$ & كايى \\
\hline سMD/. &.$/ 419$ & 4 & G/.ru & نسبت درست نمايى \\
\hline.$/ 011$ & & & $\Delta / \Delta V F$ & آزمون دقيق فيشر \\
\hline
\end{tabular}

مستر و رويكرد غنى سازى رابطه ، به نقاط مركزى همبستخى و انعطاف يذيرى تمايلى نشان ندهند.

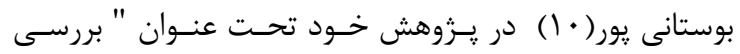

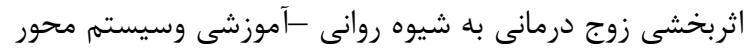

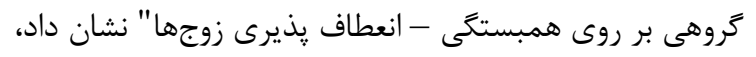

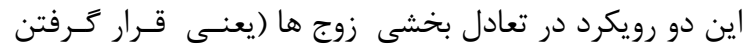

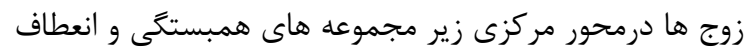

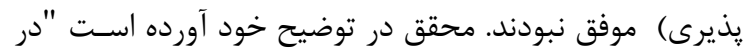
فرهنَ ما رابطه زناشويى مطلوب، يكى رابطه تنيده اسـت كـهـ

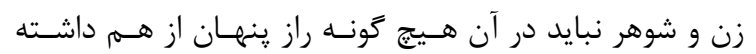

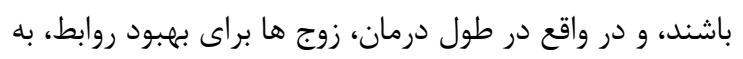

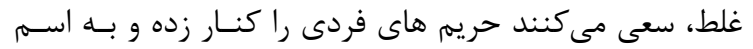
بهبود رابطه، تمام مسائل خصوصى فردى را هـم بـراى همسـر

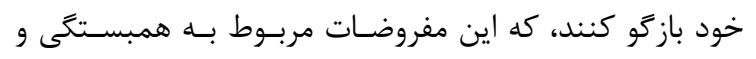
سلامت رابطه زوجى در تناقض است". همان طور كه مشـاهده مىشود يافته هاى اين يزوهش بـا يافتـه هــاى بوسـتانى يـور

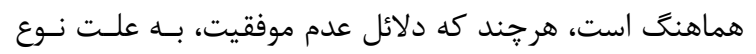

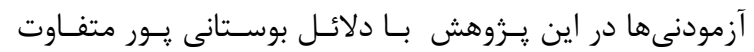

هستند.

اما در يزوهش ديخر كه توسط بابا خـانى (1 (1) تحـت عنـوان

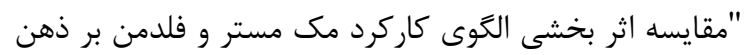

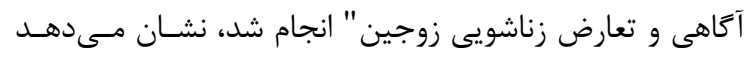

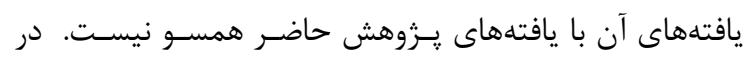

بحث روابط زناشويى با كيفيـت و همـراه بــا رضـايتمنــدى يكـى از

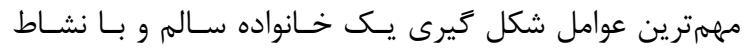

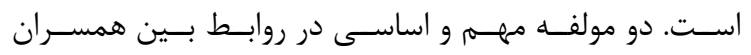

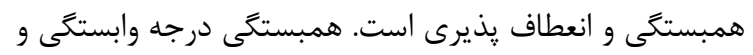

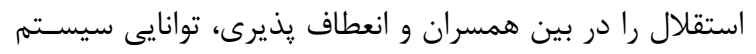

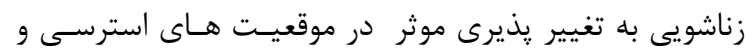

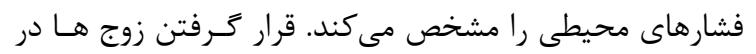

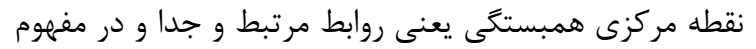

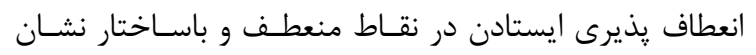

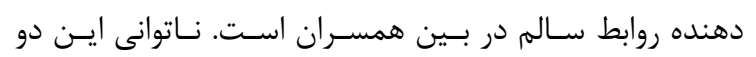
رويكرد در تاثير گذارى بر مفاهيم همبستگى و انعطاف يذيرى رون

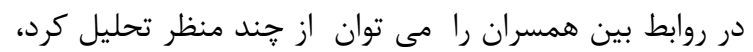

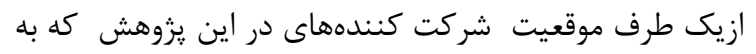
عنوان مهاجرين جديد، به علـت شـكنـنده بـودن موقعيتشـان،

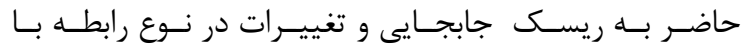

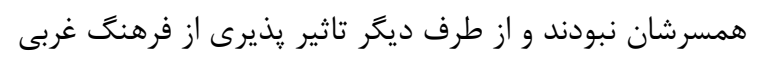

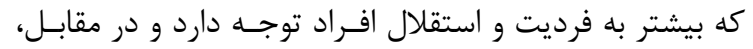

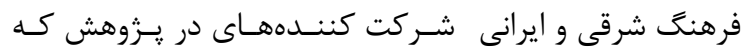

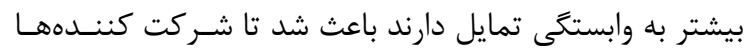
دست به تغيير در فاصله ارتباطى خود با همسرانشـان نزنــد و ولهـ

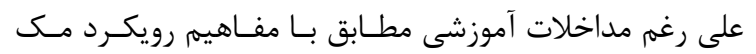




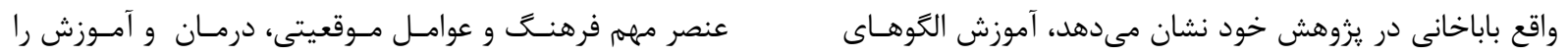

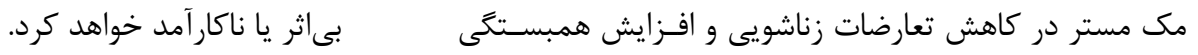

$$
\begin{aligned}
& \text { موثر است. }
\end{aligned}
$$

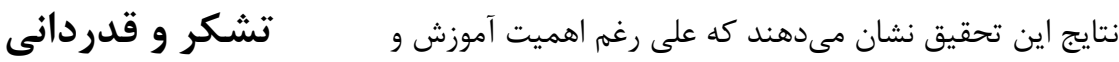

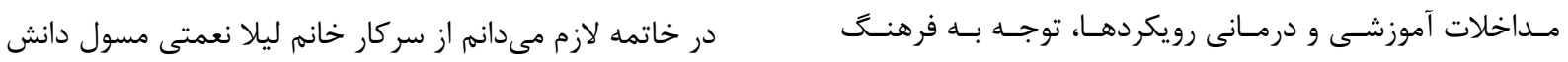

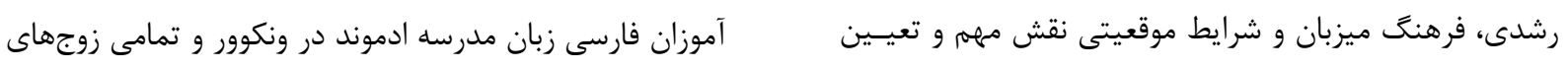

$$
\begin{aligned}
& \text { كنندهاى را در روابط بين اعضاى خانواده، به خصوص همسران }
\end{aligned}
$$

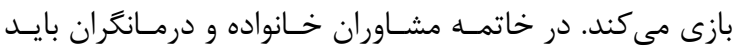

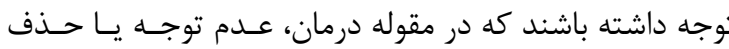

\section{REFERENCES}

1- Minuchin S, Nichols MP, Lee WY. Assessing families and couples: from symptom to systems. NY: Pearson Pub; 2007.

2- Hossaini Z. Review of cognition - behavior therapy on reality attitude on marital satisfaction [Master of counseling thesis]. Tehran: Allameh Tabatabai University; 2000. [In Persian]

3- Gurman AS. Clinical handbook of couple therapy. NY: The Guilford Press; 2008.

4- Olson DH. Circumplex model of marital and family systems. J Marital Fam Ther 2000;22:144-67.

5- Sperry L. Assessment of couples and families: contemporary and cutting-edge strategies. NY: Bruner-Rutledge; 2004.

6- Tuzer V, Tuncel A, Goka S, Dogan Bulut S, Yuksel F, V Atan A, et al. Marital adjustment and emotional symptoms in infertile couples: gender differences. Turk J Med Sci 2010; 40: 229-237.

7- Kinunnen U, Feldt T. Economic stress and marital adjustment among couples: analyses at the dyadic level. Eur Rev Soc Psychol 2004;519-32.

8- Langer SL, Yi JC, Storer BE, Syrjala, KL. Marital adjustment, satisfaction and dissolution among hematopoietic stem cell transplant patients and spouses: a prospective, five-year longitudinal investigation. Psycho-Oncology 2010;19:190-200.

9- Scuka R. The radical nature of Relationship Enhancement Expressive Skill and its implications for therapy and psychoeducation. Fam J 2011;19:30-5.

10- Boostanipor A, Sanaei B, Nazari A. Comparing effects of psycho-education programme and systems-centered group counseling on adjustment and cohesion of couples. Research in Counselling 2013;2:14-36. [In Persian]

11- Babakhani V, Navabinejad S, Shafiabadi A, Kiamanesh A. Effects of Macmaster and Feldman model on couples mindfulness and conflicts. Family Psychology 2015;2:79-92. [In Persian] 